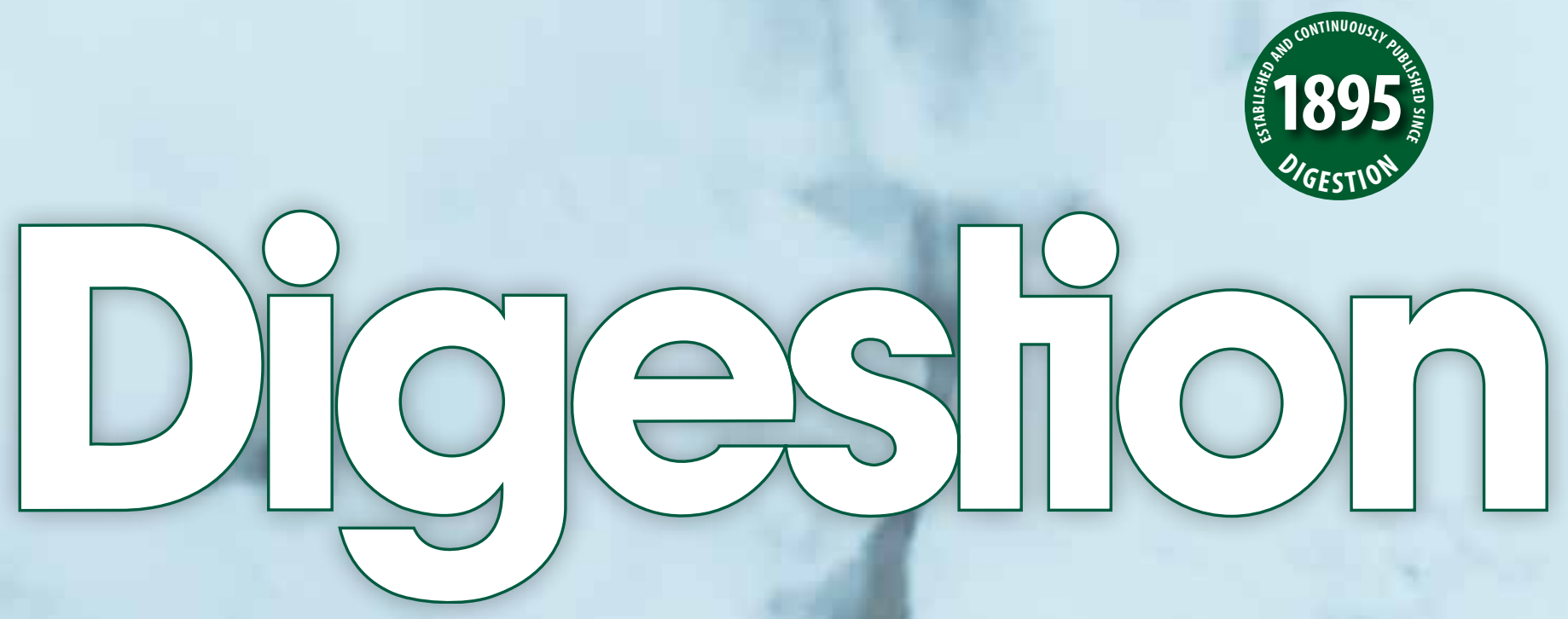




\section{New Journal}

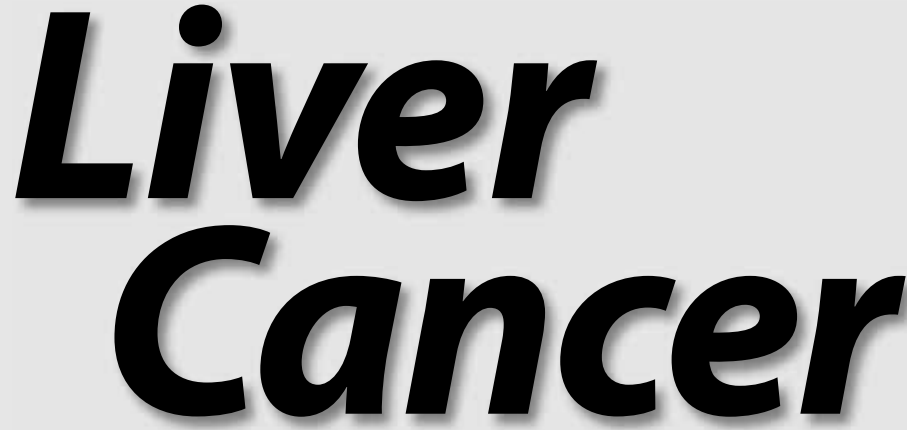

Clinical Reviews

Editior

M. Kudo, Osaka

Associate Editors

P.-J. Chen, Taipei

A.-L. Cheng, Taipei

K.-H. Han, Seoul

N. Izumi, Tokyo

N. Kokudo, Tokyo
J.M. Lee, Seoul

R. Lencioni, Pisa

J. Ricke, Magdeburg

L.R. Roberts, Rochester, Minn.

M. Sakamoto, Tokyo

A. Villanueva, Barcelona

S.-L. Ye, Shanghai

A.X. Zhu, Boston, Mass.
Affiliated with the Asia-Pacific Primary Liver Cancer Expert Meeting (APPLE)

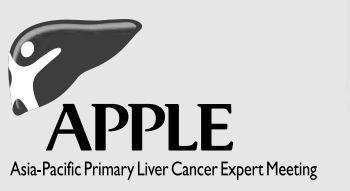

More information at

\section{www.karger.com/lic}

- Pay-per-View and Subscriber Access to Full Text

- Full Table of Contents

- Full Editorial Board

- Free Abstracts and Selected Articles

- Online Sample Issue

- Submission/Guidelines for Authors

- Subscription Details

- Free Alert Service

- Online Library Recommendation

\section{Contents of the first issue}

- Welcome to the First Issue of Liver Cancer: Kudo, M. (Osaka)

- Epidemiology and Surveillance of Hepatocellular Carcinoma: Kim, D.Y.;

Han, K. (Seoul)

- Clinical Application of Fluorescence Imaging of Liver Cancer Using Indocyanine Green: Kokudo, N.; Ishizawa, T. (Tokyo)

- Recent Advances in CT and MR Imaging for Evaluation of Hepatocellular

Carcinoma: Lee, J.; Yoon, J.H.; Joo, I.; Woo, H.S. (Seoul)

- Chemoembolization in Patients with Hepatocellular Carcinoma: Lencioni, R. (Pisa)

- Noninvasive Diagnosis of Hepatocellular Carcinoma in Cirrhotic Liver: Current Guidelines and Future Prospects for Radiological Imaging: Ricke, J.;

Seidensticker, M.; Mohnike, K. (Magdeburg)

\section{Submission of papers}

The editor cordially invites you to submit your clinical review paper to Liver Cancer. Manuscripts written in English should be submitted to the Editorial Assistant, Ms. Tanja Sebuk: t.sebuk@karger.ch
Liver cancer has a very high prevalence among cancers in general and is one of the most common causes of death worldwide. Based on these facts, the journal Liver Cancer serves the growing need to better understand the causes, mechanisms and therapy of the malignancy. It provides the international community of researchers and clinicians with a platform for their research results, focusing on molecular carcinogenesis, prevention, surveillance, diagnosis and treatment, including molecular targeted therapy, of the disease. Liver Cancer publishes clinical and translational research related to the field of liver cancer in both humans and experimental models in the form of review articles.

\section{Liver Cancer}

2013: Volume 2

4 issues per volume

Language: English

ISSN 2235-1795

ISSN online 1664-5553 

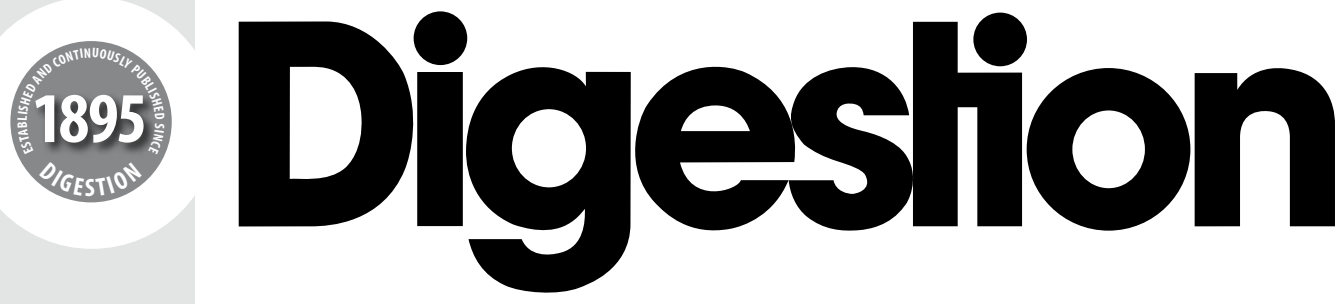

\section{International Journal of Gastroenterology}

Founded as 'Archiv für Verdauungskrankheiten' 1895 by I. Boas

Continued as 'Gastroenterologia' 1939-1967

Former Editors: P. Morawitz (1934-1936), R. Staehelin (1937-1943), A. Hurst (1940-1945),

W. Löffler (1943-1961), T.C. Hunt (1947-1967), N. Henning (1953-1962), B. Ihre (1953-1967),

H. Bartelheimer (1963-1967), M. Demole (1963-1971), H. Kapp (1968-1970),

R. Lambert (1972-1978), W. Creutzfeldt (1979-1992), R. Arnold (1993-2003),

C. Beglinger (2004-2011)

\section{Editors-in-Chief}

B. Göke, Munich

Y. Shinomura, Sapporo

\section{Managing Editors}

F. Kolligs, Munich

C. Rust, Munich

\section{Associate Editors}
A. Andoh, Otsu
A. Canbay, Essen
V. Ellenrieder, Marburg
W. Fischbach, Aschaffenburg
E. Gallmeier, Munich
G. Holtmann, Brisbane, Qld.
R. Jakobs, Ludwigshafen
Y. Kinoshita, Izumo
G. Rogler, Zurich
Y. Sasaki, Kumamoto
T. Takayama, Tokushima
K. Takeuchi, Kyoto

Official Journal of

The Japanese

Gastroenterological

Association (JGA)

\section{JGA Editorial Representatives}

Y. Kinoshita, Izumo

K. Higuchi, Osaka

Printed in Switzerland on acid-free and non-aging paper (ISO 9706) by

Reinhardt Druck, Basel
Appears every 6 weeks: 2 volumes per year (8 issues) 


\section{Submission}

'Digestion' invites papers covering investigative physiology in humans and animals, metabolic studies, and clinical work on etiology, diagnosis, and therapy of human diseases. Original papers and reviews written in English are considered and should be submitted online at

\section{www.karger.com/dig}

Authors may suggest up to five Referees who have expert knowledge on the subject. Suggested Referees should not be from the same institution, not have published with the authors during the last 5 years, and should not be prejudiced.Should you experience problems with your submission, please contact

S. Karger AG

Editorial Office 'Digestion'

PO Box

CH-4009 Basel (Switzerland)

Tel. +41613061361

Fax +41613061434

E-Mail dig@karger.com

\section{Conditions}

All manuscripts are subject to editorial review. Manuscripts are received with the explicit understanding that they are not under simultaneous consideration by any other publication. Submission of an article for publication implies transfer of the copyright from the author to the publisher upon acceptance. Accepted papers become the permanent property of 'Digestion' and may not be reproduced by any means, in whole or in part, without the written consent of the publisher. It is the author's responsibility to obtain permission to reproduce illustrations, tables, etc. from other publications.

\section{Authorship}

Each author must have participated substantially in the work to take public responsibility for the content of the paper, and must give final approval of the final version of the manuscript.

\section{Categories of Manuscripts}

Original Papers are full-length research papers which will be considered for the journal. Articles cover topics relevant to clinical and basic studies in the following areas: Physiology • Pathophysiology • Immunology • Cell Biology • Molecular Biology • Genetics • Nutrition - Epidemiology • Therapy.

Special Reviews are comprehensive, state-of-the-art reviews of important clinical problems. Reviews may be invited by the Editors or they may be unsolicited views. Abstract is required and should be divided into Background, Summary and Key Message. Reviews should consist of a maximum of 4,000 words.

Short Communications should not contain more than 2 printed pages (i.e. 5 manuscript pages), including an abstract, essential references and not more than 3 tables or figures. Such communications should represent complete, original studies and should be arranged in the same way as full length manuscripts

Meeting Reports are brief summaries of scientific meetings of gastrointestinal or liver topics. Authors should write a letter to the Editors inquiring about potential interest before submitting the paper.

Editorials provide comments on papers published in 'Digestion'. Editorials are usually invited by the Editors.

\section{Conflicts of Interest}

Authors are required to disclose any sponsorship or funding arrangements relating to their research and all authors should disclose any possible conflicts of interest. Conflict of interest statements will be published at the end of the article.

\section{Ethics}

Published research must comply with the guidelines for human studies and animal welfare regulations. Authors should state that subjects have given their informed consent and that the study protocol has been approved by the institute's committee on human research. Further, they should also state that animal experiments conform to institutional standards.

\section{Plagiarism Policy}

Whether intentional or not, plagiarism is a serious violation. We define a case of plagiarism if there is $25 \%$ similarity in the text that exactly reproduces another paper without citation.

If evidence of plagiarism is found before/after acceptance or after publication of the paper, the author will be offered a chance for rebuttal. If the arguments are not found to be satisfactory, the manuscript will be retracted and the author sanctioned from publishing papers for a period to be determined by the responsible Editor(s).

\section{Arrangement}

Title page: The first page of each paper should indicate the title, the authors' names, the institute where the work was conducted, and a short title for use as running head.

Full address: The exact postal address of the corresponding author complete with postal code must be given at the bottom of the title page. Please also supply phone and fax numbers, as well as e-mail address.

Key words: Please supply 3-10 key words in English that reflect the content of the paper.

Abstract: Each paper needs an abstract of up to 200 words. It should be structured as follows:

Background/Aims: What is the major problem that

prompted the study?

Methods: How was the study performed?

Results: Most important findings?

Conclusion: Most important conclusion?

Abstracts of Reviews: Should be divided into the following subsections: Background, Summary and Key Messages. The Background should provide a brief clinical context for the review and is followed by the Summary, which should include a concise description of the main topics covered in the text. The Key Messages encapsulate the main conclusions of the review.

Footnotes: Avoid footnotes.

Tables and illustrations: Tables and illustrations (both numbered in Arabic numerals) should be prepared on separate pages. Tables require a heading and figures a legend, also prepared on a separate page. Due to technical reasons, figures with a screen background should not be submitted. When possible, group several illustrations in one block for reproduction (max. size $180 \times 223 \mathrm{~mm}$ ) or provide crop marks. Each illustration must be labelled with its number and the first author's name. $\mathrm{B} / \mathrm{w}$ half-tone and color illustrations must have a final resolution of $300 \mathrm{dpi}$ after scaling, line drawings one of 800-1,200 dpi. Figure files must not beembedded in adocumentfile but submitted separately (see detailed instructions on the Submission Website at www.karger.com/dig).

Color illustrations

Online edition: Color illustrations are reproduced free of charge. In the print version, the illustrations are re- produced in black and white. Please avoid referring to the colors in the text and figure legends.

Print edition: Up to 6 color illustrations per page can be integrated within the text at CHF 800.- per page.

References: In the text identify references by Arabic numerals [in square brackets]. Material submitted for publication but not yet accepted should be noted as 'unpublished data' and not be included in the reference list. The list of references should include only those publications which are cited in the text. Do not alphabetize; number references in the order in which they are first mentioned in the text. The surnames of the authors followed by initials should be given. There should be no punctuation other than a comma to separate the authors. Preferably, please cite all authors. Abbreviate journal names according to the Index Medicus system. Also see International Committee of Medical Journal Editors: Uniform requirements for manuscripts submitted to biomedical journals (www.icmje.org)

Examples

(a) Papers published in periodicals: Chatel J-M, Bernard $\mathrm{H}$, Orson FM: Isolation and characterization of two complete Ara h 2 isoforms cDNA. Int Arch Allergy Immunol 2003;131:14-18.

(b) Papers published only with DOI numbers:

Theoharides TC, Boucher W, Spear K: Serum interleukin-6 reflects disease severity and osteoporosis in mastocytosis patients. Int Arch Allergy Immunol DOI: 10.1159/000063858.

(c) Monographs: Matthews DE, Farewell VT: Using and Understanding Medical Statistics, ed 3, revised. Basel, Karger, 1996.

(d) Edited books: DuBois RN: Cyclooxygenase-2 and colorectal cancer; in Dannenberg AJ, Dubois RN (eds): COX-2. Prog Exp Tum Res. Basel, Karger, 2003, vol 37, pp 124-137.

Reference Management Software: Use of EndNote is rec ommended for easy management and formatting of $\mathrm{ci}$ tations and reference lists.

\section{Digital Object Identifier (DOI)}

S. Karger Publishers supports DOIs as unique identifiers for articles. A DOI number will be printed on the title page of each article. DOIs can be useful in the future for identifying and citing articles published online without volume or issue information. More information can be found at www.doi.org.

\section{Supplementary Material}

Supplementary material is restricted to additional data that are not necessary for the scientific integrity and conclusions of the paper. Please note that all supplementary files will undergo editorial review and should be submitted together with the original manuscript. The Editors reserve the right to limit the scope and length of the supplementary material. Supplementary material must meet production quality standards for Web publication without the need for any modification or editing. In general, supplementary files should not exceed $10 \mathrm{MB}$ in size. All figures and tables should have titles and legends and all files should be supplied separately and named clearly. Acceptable files and formats are: Word or PDF files, Excel spreadsheets (only if the data cannot be converted properly to a PDF file), and video files (.mov, .avi, .mpeg).

Author's Choice ${ }^{\mathrm{TM}}$

Karger's Author's Choice ${ }^{\mathrm{TM}}$ service broadens the reach of your article and gives all users worldwide free and full access for reading, downloading and printing at www.karger.com. The option is available for a one-time

\section{KARGER}

E-Mail karger@karger.com www.karger.com
(C) 2013 S. Karger AG, Basel 
fee of CHF 3000.-, which is a permissible cost in grant allocation. More information can be found at www. karger.com/authors_choice.

\section{NIH-Funded Research}

The U.S. National Institutes of Health (NIH) mandates under the NIH Public Access Policy that final, peer-reviewed manuscripts appear in its digital database within 12 months of the official publication date. As a service to authors, Karger submits the final version of your article on your behalf to PubMed Central. For those selecting our premium Author's Choice ${ }^{\mathrm{TM}}$ service, we will send your article immediately upon publishing, accelerating the accessibility of your work without the usual embargo. More details on NIH's Public Access Policy is available at http://publicaccess.nih.gov/policy.htm.

\section{Self-Archiving}

Karger permits authors to archive their pre-prints (i.e. pre-refereeing) or post-prints (i.e. final draft post-refereeing) on their personal or institution's servers, provided the following conditions are met: Articles may not be used for commercial purposes, must be linked to the publisher's version, and must acknowledge the publisher's copyright. Authors selecting Karger's Author's Choice ${ }^{\mathrm{TM}}$ feature, however, are also permitted to archive the final, published version of their article, which includes copyediting and design improvements as well as citation links.

\section{Page Charges}

There are no page charges for papers of 3 or fewer printed pages (including tables, illustrations and references).
Each additional complete or partial page is charged to the author at CHF 325.-. The allotted size of a paper is equal to approx. 10 manuscript pages (including tables, illustrations and references).

\section{Proofs}

Unless indicated otherwise, proofs are sent to the corresponding author and should be returned with the least possible delay. Alterations other than the correction of printer's errors are charged to the author.

\section{Reprints}

Order forms and a price list are sent with the proofs. Orders submitted after the issue is printed are subject to considerably higher prices.

\section{KARGER BOOKS ON MEDICAL PHILOSOPHY}

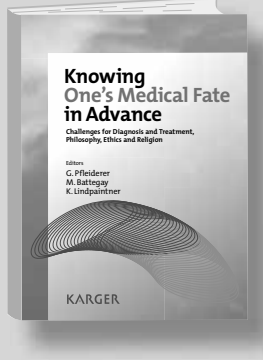

Knowing One's

\section{Medical Fate in Advance}

Challenges for Diagnosis and Treatment, Philosophy, Ethics and Religion

Editors: G. Pfleiderer, M. Battegay, K. Lindpainter

$\mathrm{VI}+122$ p., 4 fig., 2 in color, hard cover, 2012

CHF 59. - / EUR 49.- / USD 69.00

ISBN 978-3-8055-9649-7

The certainty and uncertainty of one's fate are discussed from both methodological and epidemiological perspectives, using examples of diseases for which treatment and prognosis have dramatically changed. Despite profound insights into the human genome, personalized genetically tailored medicine still lies in the future. Religious, spiritual and philosophical dimensions are discussed, as are the ways in which they may help people cope with these new insights into their future, e.g. the promise of an afterlife.

This publication aims to bridge the different fields dealing with this area by addressing the challenges faced and encouraging dialogue. It will be of interest to all readers who deal with ethical problems of prognosis, particularly in medicine, as well as to theologians and sociologists.

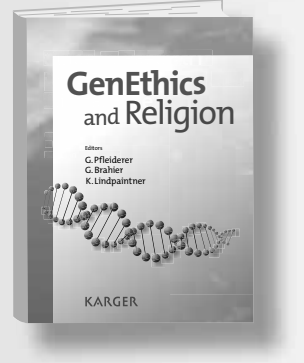

\section{GenEthics and Religion}

Editors: G. Pfleiderer, G. Brahier K. Lindpaintner

$\mathrm{VI}+154$ p., hard cover, 2010

CHF 29.- / EUR 24.- / USD 34.00

ISBN 978-3-8055-8973-4

Prices subject to change;

EUR price for Germany, USD price for USA only
Based on the symposium 'GenEthics and Religion' (Basel, Switzerland, May 2008), this volume examines the role religion can play in establishing ethical guidelines to protect human life in the face of rapid advances in biology and gene technology. It does so with contributions by philosophers, theologians, human geneticists, and several bioethicists representing the Christian, Jewish, Islamic and Buddhist perspectives. The essays illustrating a diversity of views and expressing the problems and self-critical reflectiveness of religious ethicists are brought up to date and discuss the importance of religious ethics in society's discourse on gene technology.

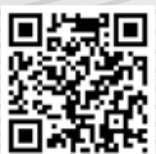

More information at www.karger.com/philosophy 
Digestion

ISSN Print Edition: 0012-2823

ISSN Online Edition: 1421-9867

Journal Homepage: www.karger.com/dig

Publication Data: 'Digestion' is published 8 times a year. Volumes 87 and 88 , each with 4 issues, appear in 2013.

Copyright: (c) 2013 S. Karger AG, Basel (Switzerland). All rights reserved. No part of this publication may be translated into other languages, reproduced or utilized in any form or by any means, electronic or mechanical, including photocopying, recording, microcopying, or by any information storage and retrieval system, without permission in writing from the publisher or, in the case of photocopying, direct payment of a specified fee to the Copyright Clearance Center.

Disclaimer: The statements, opinions and data contained in this publication are solely those of the individual authors and contributors and not of the publisher and the editor(s). The appearance of advertisements in the journal is not a warranty, endorsement, or approval of the products or services advertised or of their effectiveness, quality or safety. The publisher and the editor(s) disclaim responsibility for any injury to persons or property resulting from any ideas, methods, instructions or products referred to in the content or advertisements.
Subscription Rates: Subscriptions run for a full calendar year. Prices are given per year. Personal subscription:

Print or Online

CHF 589.-

EUR 475.-

USD 583.00

Print+Online combined CHF 685.-

EUR 553.-

USD 679.00

postage and handling (added to print and print+online)

CHF 57.60 Europe, CHF 83.20 Overseas

EUR 44.80

USD 76.80

Institutional subscription:

Print or Online

Print+Online combined

CHF 2944.-

EUR 2374.-

CHF 3238.-

EUR 2612.-

USD 3206.00

postage and handling (added to print and print+online)

CHF 72.- Europe, CHF 104.- Overseas

EUR 56.-

USD 96.00

Airmail surcharge: CHF 70.- / USD 66.-

Discount subscription prices:

Please enquire about reduced rates for members of affiliated societies.
Back Volumes and Single Issues: Information on availability and prices of single print issues and print or electronic back volumes can be obtained from Customer Service atservice@karger.com.

Bibliographic Indices: This journal is regularly listed in bibliographic services, including Current Contents ${ }^{\circledR}$ and PubMed/MEDLINE.

Photocopying: This journal has been registered with the Copyright Clearance Center (CCC), as indicated by the code appearing on the first page of each article. For readers in the US, this code signals consent for copying of articles for personal or internal use, or for the personal or internal use of specific clients, provided that the stated fee is paid per copy directly to

Copyright Clearance Center Inc.

222 Rosewood Drive

Danvers, MA 01923 (USA)

A copy of the first page of the article must accompany payment. Consent does not extend to copying for general distribution, for promotion, for creating new works, or for resale. In these cases, specific written permission must be obtained from the copyright owner,

S. Karger AG, P.O. Box

CH-4009 Basel (Switzerland).
Subscription Orders:

Orders can be placed at agencies, Orders can be placed at agencies,
bookstores, directly with the Publisher

Medical and Scientific Publishers

Allschwilerstrasse 10

CH-4009 Basel

Switzerland

t: +41613061111

f: +41613061234

e: karger@karger.com

w: www.karger.com

(for courier services only:

Allschwilerstrasse 10

CH-4055 Basel)

\section{S. Karger AG}

\begin{tabular}{|c|c|}
\hline $\begin{array}{l}\text { or further Karger offices } \\
\text { or representatives: }\end{array}$ & $\begin{array}{l}\text { USA } \\
\text { S. Karger Publishers, Inc. } \\
26 \text { West Avon Road }\end{array}$ \\
\hline Germany & P.O. Box 529 \\
\hline S. Karger GmbH & Unionville, CT 06085 \\
\hline Postfach & USA \\
\hline 79095 Freiburg & Toll free: +1 8008285479 \\
\hline Deutschland & $\mathrm{t}: \quad+18606757834$ \\
\hline (Hausadresse: Wilhelmstrasse 20A, & f: +18606757302 \\
\hline 79098 Freiburg) & e: karger@snet.net \\
\hline t: $\quad+49761452070$ & \\
\hline f: $\quad+497614520714$ & France \\
\hline $\begin{array}{l}\text { e: information@karger.de } \\
\text { w: www.karger.de }\end{array}$ & $\begin{array}{l}\text { Librairie Médi-Sciences Sarl } \\
\text { 36, bd de Latour-Maubourg } \\
\text { 75007 Paris }\end{array}$ \\
\hline Japan & France \\
\hline Karger Japan, Inc. & $\mathrm{t}: \quad+33(0) 145514258$ \\
\hline Shiba Daimon Asahi Bldg. 2F & f: $+33(0) 145560780$ \\
\hline 1-2-23 Shiba Daimon & e: librairie@medi-sciences.fr \\
\hline Minato-ku & w: www.medi-sciences.fr \\
\hline Tokyo 105-0012 & \\
\hline Japan & \\
\hline $\mathrm{t}: \quad+81364356242$ & \\
\hline $\mathrm{f}:+81364356244$ & \\
\hline e: publisher@karger.jp & \\
\hline
\end{tabular}

Change of Address:

Both old and new address should be sent

to the subscription source.

\section{KARGER}

E-Mail karger@karger.com www.karger.com
(C) 2013 S. Karger AG, Basel

The Journal Home Page is available at:

www.karger.com/dig
South East Asia, China and Taiwan Karger Regional Office (Malaysia)

CEO Suite Kuala Lumpur

Quill 7, 27th Floor

Jalan Stesen Sentral 5

KL Sentral

Kuala Lumpur 50470

Malaysia

t: +60327766803

f: +60327766999

e: service@karger.cn; r.chew@karger.cn

\section{Karger China}

10th Floor, Twin Towers (East)

B12 Jianguomenwai Avenue

Beijing 100022

China

$\mathrm{t}:+861051235033$

f: +861051235122

e: service@karger.cn; r.chew@karger.cn

w: www.karger.cn

India, Bangladesh, Sri Lanka

Medscience India

Plot No. 17, Yusuf Sarai Market

B.L. Glass Building, 2nd Floor

Sri Aurobindo Marg

New Delhi 110016

India

t: +911146029633

f: +911146029634

c: +919891052128

e: medsci.india@gmail.com 


\section{Contents}

See the journal website for contents

KARGER Basel $\bullet$ Freiburg $\cdot$ Paris $\bullet$ London $\bullet$ New York $\cdot$ New Delhi $•$ Bangkok Beijing $\cdot$ Tokyo $\cdot$ Kuala Lumpur $\cdot$ Singapore $\bullet$ Sydney 


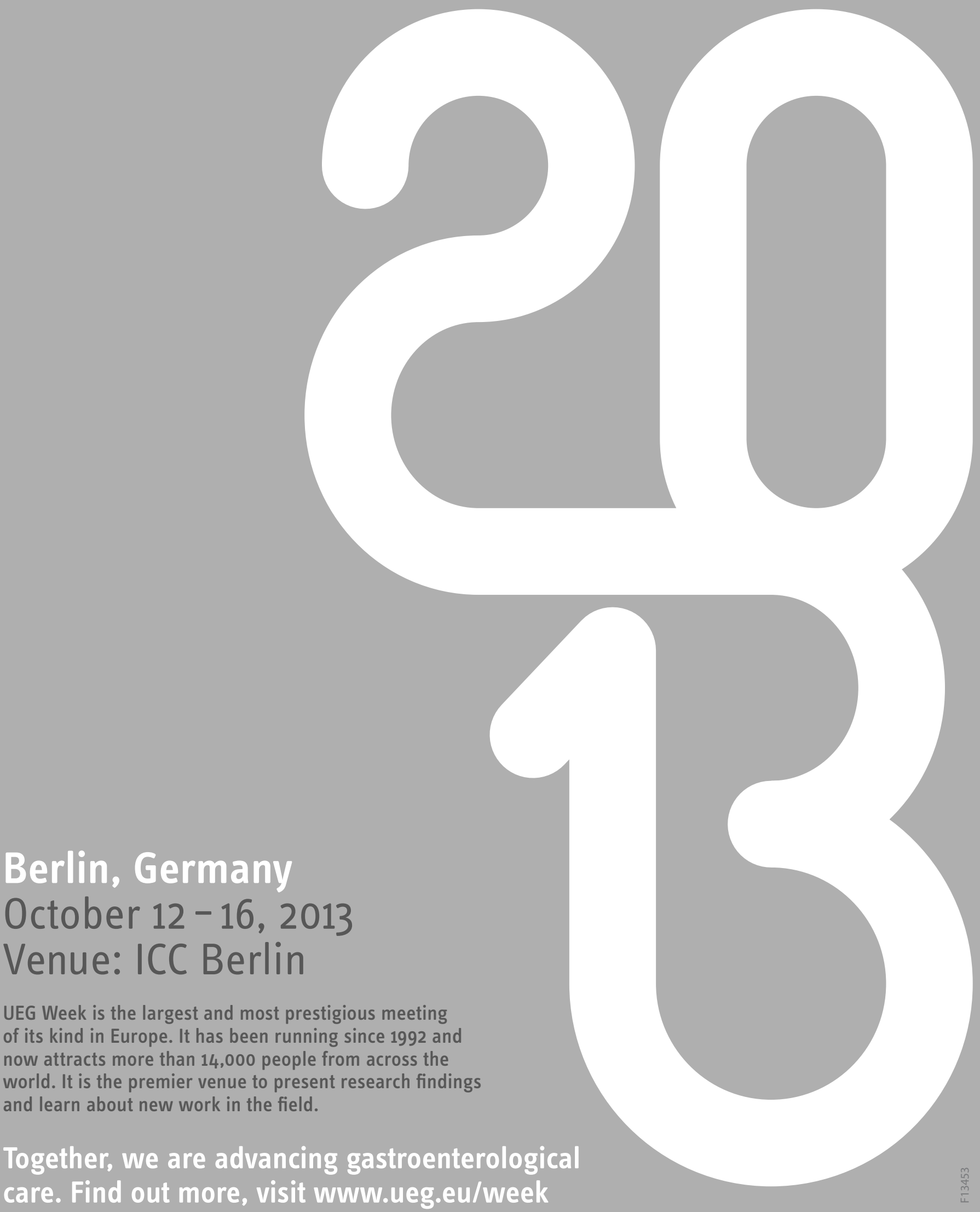




\title{
Innate Immunity in Digestive Diseases Gastrointestinal Disorders: Basic and Therapeutic Concepts
}

\author{
Editors \\ H. Tilg, R.S. Blumberg, S. Endres, A. Kaser, M.P. Manns
}

Innate Immunity in Gastrointestinal Disorders: Basic and Therapeutic Concepts Editors: Tilg, H. (Innsbruck);

Blumberg, R.S. (Boston, Mass.);

Endres, S. (Munich); Kaser, A. (Cambridge); Manns, M.P. (Hannover)

IV + 110 p., 16 fig., 11 tab., 2012

CHF 48.- / EUR 40.- / USD 56.00 (soft cover)

CHF 58- / EUR 48. - / USD 67.00 (online)

Online version for institutional purchase

Prices subject to change

EUR price for Germany, USD price for USA only ISBN 978-3-318-02208-7 (soft cover)

e-ISBN 978-3-318-02209-4

Special Topic Issue:

Digestive Diseases

Vol. 30, Suppl. 1 (2012)

Included in subscription

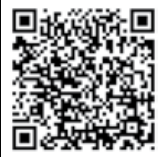

Dear Librarian

I have reviewed this publication and would like to recommend it for our library.

Recommended by:

Department:

\section{Contents}

Preface

-Innate Immunity in Gastrointestinal Disorders:

Basic and Therapeutic Concepts: Tilg, H.; Blumberg, R.; Enders, S.; Kaser, A.; Manns, M.

\section{Autoimmune Liver Disease and PBC}

From Animal Models to Innovative Therapies

- Animal Models for Autoimmune Liver Disease -

What Is Relevant for Immune-Mediated Liver

Disease: Hardtke-Wolenski, M.; Taubert, R.; Jaeckel, E.

-Autoimmune Hepatitis: New Guidelines,

New Therapies: Strassburg, C.P.

-What Is New in Primary Biliary Cirrhosis?

Bogdanos, D.P.; Gershwin, M.E.

Innate Immunity: Key Role in Liver Disorders

- A Lecture on the Genetics of Primary Sclerosing

Cholangitis: Karlsen, T.H.

-Primary Sclerosing Cholangitis: New Approaches

to Diagnosis, Surveillance and Treatment:

Trauner, M.; Halilbasic, E.; Baghdasaryan, A.; Moustafa, T.;

Krones, E.; Fickert, P.; Hofer, H.; Penner, E.

-NK Cells in Hepatitis C: Role in Disease

Susceptibility and Therapy: Lunemann, S.;

Schlaphoff, V.; Cornberg, M.; Wedemeyer, H.

Fatty Liver Diseases: Innate Immunity as Driving Force for Metabolic Inflammation?

- Innate Immunity and Alcoholic Liver Disease:

Szabo, G.; Petrasek, J.; Bala, S.
Fatty Liver Diseases:

Histopathology and Treatment

- Nonalcoholic Fatty Liver Disease: What the

Pathologist Can Tell the Clinician: Brunt, E.M.

- Clinical Spectrum and Therapy of Non-Alcoholic

Steatohepatitis: Day, C.P.

-Toll-Like Receptors in Gastrointestinal Diseases: Wagner, $\mathrm{H}$.

The New World of IBD:

About Genes, Bacteria and Viruses

- The Genetics Universe of Crohn's Disease and

Ulcerative Colitis: Parkes, $\mathbf{M}$.

Focus on Innate Immunity in IBD

- Protective and Aggravating Effects of Nlrp3

Inflammasome Activation in IBD Models: Influence

of Genetic and Environmental Factors: Bauer, C.;

Duewell, P.; Lehr, H.-A.; Endres, S.; Schnurr, M.

-Animal Models of Inflammatory Bowel Diseases:

Illuminating the Pathogenesis of Colitis, Ileitis and

Cancer: Neurath, M.F.

\section{Treatment Update of IBD}

-Predicting the Course of IBD: Light at the End of the Tunnel? Lee, J.C.

The Future of IBD: Genetics Meets Therapeutics - New Drug Therapies on the Horizon for IBD:

Perrier, C.; Rutgeerts, P. 


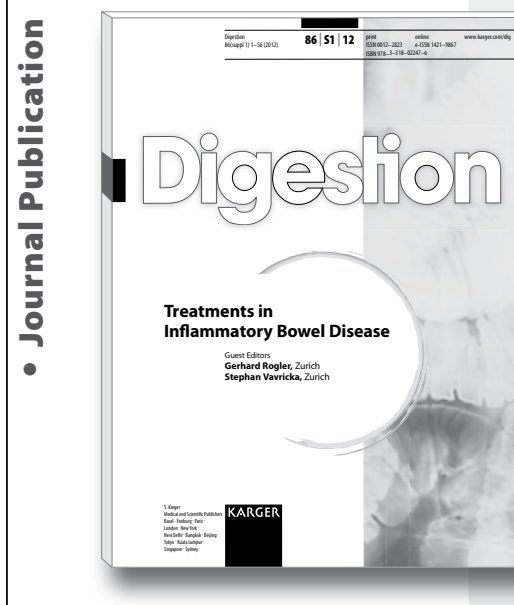

\title{
Treatments in Inflammatory Bowel Diseases
}

\author{
Editors \\ Gerhard Rogler \\ Stephan Vavricka
}

Treatments in Inflammatory Bowel Disease Editors: Rogler, G.; Vavricka, S. (Zurich)

IV + 56 p., 3 fig., 7 tab., 2012

CHF 29.- / EUR 24.- / USD 34.00 (soft cover)

CHF 35.- / EUR 29.- / USD 41.00 (online)

Online version for institutional purchase

Prices subject to change

EUR price for Germany, USD price for USA only

ISBN 978-3-318-02247-6 (soft cover)

e-ISBN 978-3-318-02248-3

Supplement Issue:

Digestion

Vol. 86, Suppl. 1 (2012)

Included in subscription

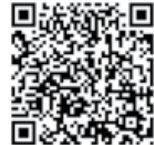

Dear Librarian

I have reviewed this publication and

would like to recommend it for our library.

Recommended by:

Department:

Date:

Signature:

Orders may be placed with any bookshop

subscription agency, directly with the publisher

or through a Karger distributor.

\section{Contents}

-Preface

-Monitoring of Therapy for Inflammatory Bowel Disease: Burri, E.; Beglinger, C.; Lehmann, F.S.

-First-Line Therapies in Inflammatory Bowel Disease: Girardin, M.; Manz, M.; Manser, C.; Biedermann, L.; Wanner, R.; Frei, P.; Safroneeva, E.; Mottet, C.; Rogler, G.; Schoepfer, A.M.

-Therapy of Steroid-Resistant Inflammatory Bowel Disease: Manz, M.; Vavricka, S.R.; Wanner, R.; Lakatos, P.L.; Rogler, G.; Frei, P.; Safroneeva, E.; Schoepfer, A.M.

-Mucosal Healing with Anti-TNF Antibodies: Chevaux, J.-B.;

Vavricka, S.R.; Rogler, G.; Lakatos, P.L.; Schoepfer, A.; Peyrin-Biroulet, L.

- Treatment of Fibrostenotic and Fistulizing Crohn's Disease: Schoepfer, A.M.; Safroneeva, E.; Vavricka, S.R.; Peyrin-Biroulet, L.; Mottet, C.

-Treatment of Extraintestinal Manifestations in Inflammatory Bowel Disease: Lakatos, P.L.; Lakatos, L.; Kiss, L.S.; Peyrin-Biroulet, L.; Schoepfer, A.; Vavricka, S.

-Topical Therapies in Inflammatory Bowel Disease: Frei, $P_{.}$. Biedermann, L.; Manser, C.N.; Wilk, M.; Manz, M.; Vavricka, S.R.; Rogler, G.

-Pregnancy and Breastfeeding in Inflammatory Bowel Disease: Biedermann, L.; Rogler, G.; Vavricka, S.R.; Seibold, F.; Seirafi, M. 


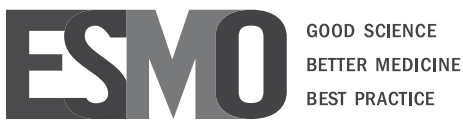

[1] Imedex

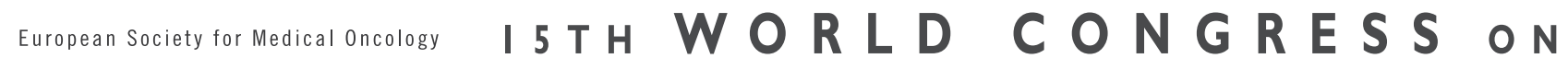

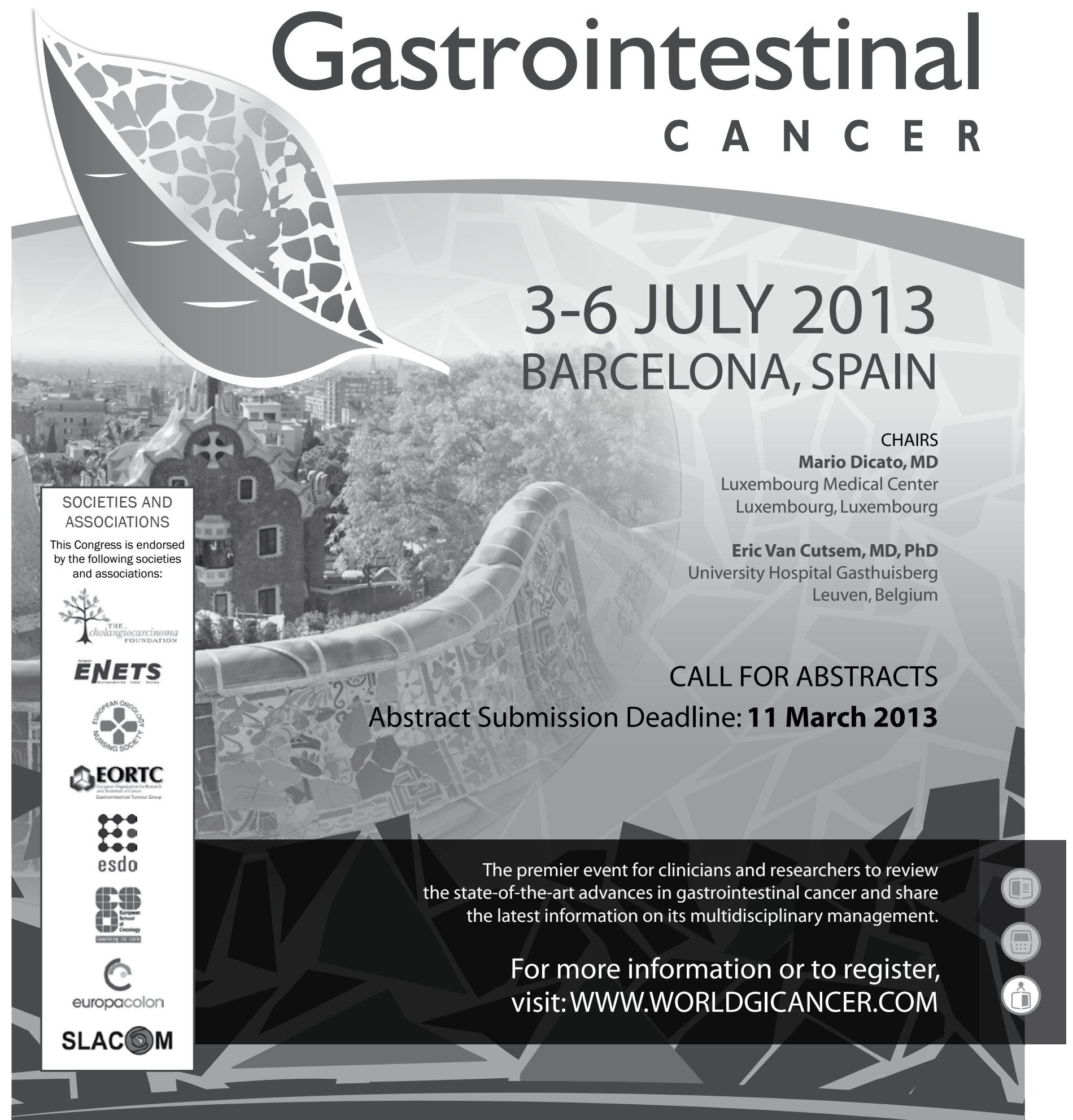

EDUCATION IS THE BEST MEDICINE ${ }^{\circledR}$ 


\section{Focussing on clinical research reports}

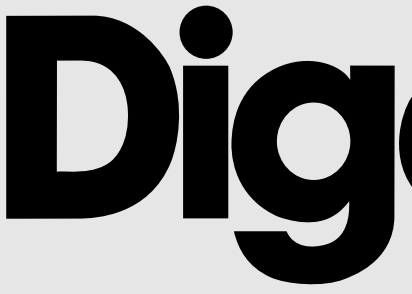

International Journal of Gastroenterology

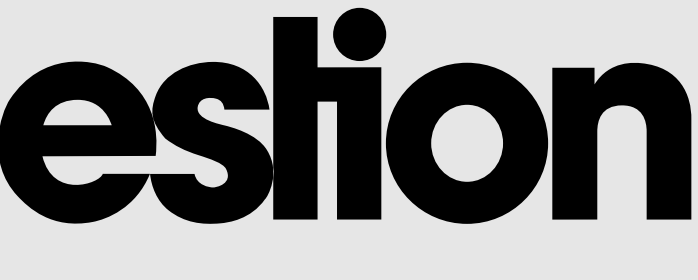

\begin{abstract}
Editors-in-Chief
\end{abstract}
B. Göke, Munich

Y. Shinomura, Sapporo
Official Journal of

The Japanese Gastroenterological Association (JGA)

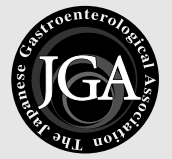

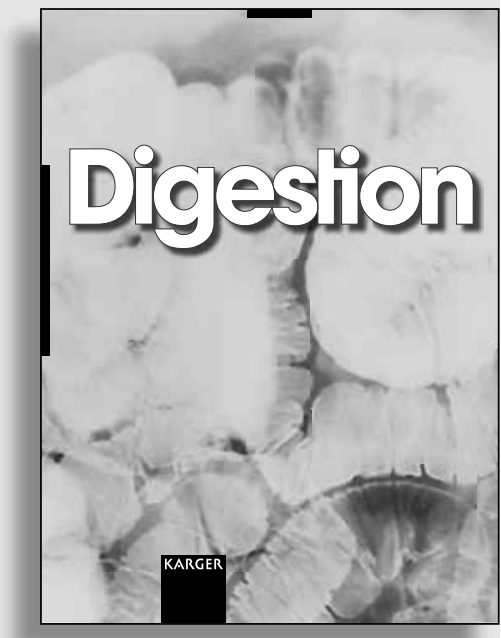

More information at

\section{www.karger.com/dig}

- Pay-per-View and Subscriber Access to Full Text

- Full Table of Contents

- Full Editorial Board

- Free Abstracts and Selected Articles

- Online Sample Issue

- Submission/Guidelines for Authors

- Subscription Details

- Free Alert Service

- Online Library Recommendation

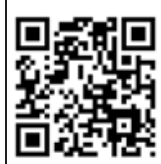

Digestion

2013: Volumes 87, 88

4 issues per volume

Language: English

ISSN 0012-2823 (print)

ISSN 1421-9867 (online)

\section{Selected contributions}

- Impact of Cannabis Treatment on the Quality of Life, Weight and Clinical Disease Activity in Inflammatory Bowel Disease Patients: A Pilot Prospective Study: Lahat, A.; Lang, A.; Ben-Horin, S. (Tel Aviv)

- Flexible Sigmoidoscopy Does Not Significantly Increase Polyp and Cancer Detection Yield when Used to Supplement CT Colonography: Selinger, C.P.; Mullender, J.; Choudhury, S.; Jones, P.E.; Sukumar, S.; Ramesh, J. (Manchester)

- The Effect of Exenatide and Erythromycin on Postprandial Symptoms and Their Relation to Gastric Functions: Yoon, S.B.; Choi, M.-G.; Lim, C.-H.; Kim, J.S.; Cho, Y.K.; Park, J.M.; Lee, I.S.; Kim, S.W.; Choi, K.Y.; Chung, I.-S. (Seoul)

- Insights Gained from Symptom Evaluation of Esophageal Motility Disorders: A Review of 4,215 Patients: Tsuboi, K.; Hoshino, M.; Srinivasan, A.; Yano, F. (Omaha, Nebr.); Hinder, R.A. (Jacksonville, Fla.); DeMeester, T.R. (Los Angeles, Calif.); Filipi, C.J.; Mittal, S.K. (Omaha, Nebr.)

- Effect of Proton-Pump Inhibitor Therapy on Serum Chromogranin A Level: Pregun, I.; Herszényi, L.; Juhász, M.; Miheller, P.; Hritz, I.; Patócs, A.; Rácz, K.; Tulassay, Z. (Budapest)

- Hypoxemia during Moderate Sedation for Gastrointestinal Endoscopy: Causes and Associations: Qadeer, M.A.; Lopez, A.R.; Dumot, J.A.; Vargo, J.J. (Cleveland, Ohio) - Gene Expression following Exposure to Celecoxib in Humans: Pathways of Inflammation and Carcinogenesis Are Activated in Tumors but Not Normal Tissues: Sagiv, E. (Tel Aviv); Sheffer, M. (Rehovot); Kazanov, D.; Shapira, S.; Naumov, I.; Kraus, S. (Tel Aviv); Domany, E. (Rehovot); Arber, N. (Tel Aviv)

- Fructose Malabsorption: How Much Fructose Can a Healthy Subject Tolerate? Frieling, T.; Kuhlbusch-Zicklam, R.; Kalde, S.; Heise, J.; Hülsdonk, A.; Kreysel, C. (Krefeld)
Digestion concentrates on clinical research reports: in addition to editorials and reviews, the journal features sections on Stomach/Esophagus, Bowel, Neuro-Gastroenterology, Liver/Bile, Pancreas, Metabolism/Nutrition and Gastrointestinal Oncology. Papers cover physiology in humans, metabolic studies and clinical work on the etiology, diagnosis, and therapy of human diseases. It is thus especially cut out for gastroenterologists employed in hospitals and outpatient units. Moreover, the journal's coverage of studies on the metabolism and effects of therapeutic drugs carries considerable value for clinicians and investigators beyond the immediate field of gastroenterology. 


\section{Editorials}

100 Heme Oxygenase and Hepatic Microcirculation: More than Just Carbon Monoxide?

Arteel, G.E. (Louisville, K.Y.)

118 Are Biomarkers Still Helpful in Hepatocellular Carcinoma?

Lamerz, R. (Munich)

Review

91 Review Article on Current Applications and Future Concepts of Capsule Endoscopy

Neumann, H. (Erlangen); Fry, L.C. (Bottrop); Neurath, M.F. (Erlangen)

\section{Original Papers}

67 Gum Chewing: Another Simple Potential Method for More Rapid Improvement of Postoperative Gastrointestinal Function

Yin, Z.; Sun, J.; Liu, T.; Zhu, Y.; Peng, S.; Wang, J. (Guangzhou)

75 Clinical Manifestations and Treatment Options in Patients with Cirrhosis and Diabetes Mellitus Gundling, F.; Seidl, H.; Strassen, I.; Haller, B.; Siegmund, T.; Umgelter, A. (Munich); Pehl, C. (Vilsbiburg); Schepp, W.; Schumm-Draeger, P.M. (Munich)
85 Patient Selection for Therapy Reduction after Long-Term Daily Proton Pump Inhibitor Treatment for Gastro-Oesophageal Reflux Disease: Trial and Error van der Velden, A.W.; de Wit, N.J.; Quartero, A.O.; Grobbee, D.E.; Numans, M.E. (Utrecht)

102 Portal Pressure Regulation following Kupffer Cell Activation: Control of Prostaglandin Production by Heme Oxygenases

Steib, C.J.; Gmelin, L. (Munich); Bilzer, M. (Haar); Göke, B.; Gerbes, A.L. (Munich)

110 Active Eosinophilic Esophagitis Is Associated with Impaired Elimination of Budesonide by Cytochrome P450 3A Enzymes

Dilger, K. (Freiburg); Lopez-Lazaro, L.; Marx, C. (Allschwil); Bussmann, C. (Lucerne); Straumann, A. (Olten)

121 A Combination of a-Fetoprotein and Des- $\gamma$-Carboxy Prothrombin Is Superior in Detection of Hepatocellular Carcinoma

Ertle, J.M.; Heider, D.; Wichert, M.; Keller, B. (Essen); Kueper, R. (Neuss); Hilgard, P. (Mülheim an der Ruhr); Gerken, G.; Schlaak, J.F. (Essen)

132 Lactulose Is Highly Potential in Prophylaxis of Hepatic Encephalopathy in Patients with Cirrhosis and Upper Gastrointestinal Bleeding: Results of a Controlled Randomized Trial

Wen, J.; Liu, Q.; Song, J.; Tong, M.; Peng, L.; Liang, H. (Beijing) 